\title{
Inequalities in Education : A Case Study of Dhubri District, Assam, India
}

\author{
Gwmsath Mushahary, Manjil Basumatary
}

\begin{abstract}
Gender inequality refers to the inequality between men and women in any aspect. Educational Inequality is the unequal distribution of educational attainment including educational opportunities and achievement within a particular region. The educational attainment between men and women always varies in our society. The literacy gap between male and female is not only found in Dhubri district alone but in the state of Assam as well. The educational achievement and work participation of women is less than men in the Dhubri district of Assam. The educational achievement and work participation gap between male and female are very high in the district of Dhubri as compared to the other districts of the state. This is mainly because of various factors such as socio-cultural background of the communities; limited access to high quality education, School environment, lack of awareness etc. The study area is populated by various communities such as Muslims, Bengalis, Rabhas, Garos, Bodos, Rajbongshis etc of which Muslims are the dominant and girls are given less preference in the Muslim society in terms of education for which there is a vast gap in the educational attainment between male and female in Dhubri district. The present study will help in reducing the inequalities, be it in education, work participation, economic upliftment etc. The objective of the study is to understand the factors of inequality between men and women in terms of educational achievement and work participation of the region and also to suggest measures to address the issue
\end{abstract}

Keywords: Educational achievement, Work participation, Economic conditions, Political pressure, Social rituals.

\section{INTRODUCTION}

Gender inequality is the unequal treatment of men and women in any aspect. Educational inequality is the unequal distribution of educational pattern of a particular region. The dimensions of inequality of education may vary from one society to another. Gender inequality is one of the most persistent problems in today's world, which leads to disparity in the society. It exists when unequal treatment takes place in the society. Gender inequality in education is a persistent problem in Indian society, especially for girls from rural areas and lower socio-economic backgrounds (Gregory et.al. 2016). The woman gets marginalized in the society and it leads to deprivation of women from their rights. Gender

Revised Manuscript Received on April 15, 2020.

* Correspondence Author

Gwmsath Mushahary*, Masters Degree, Department of Geography, Bodoland Universit

Dr. Manjil Basumatary, Teacher, Geography, Under graduate (UG) and Post Graduate(PG) level, Gossaigaon College, Gossaigaon, Kokrajahr, Assam.

(c) The Authors. Published by Blue Eyes Intelligence Engineering and Sciences Publication (BEIESP). This is an open access article under the CC BY-NC-ND license (http://creativecommons.org/licenses/by-nc-nd/4.0/)
Inequalities are found to have existed since the time human being started living in the society. The inequalities are found in education, health and employment or pay (Klasen, \& Lamanna, 2008). Inequality in education is due to neglect of girl child by parents. The women are given less importance although they manage all activities of the family. In short, they have been marginalized in many other aspects in the society.

An inequality in educational achievement in any area may take place when there is unequal distribution of educational opportunities. The major factors that contribute to educational gaps are socio-economic, accessibility to learning materials and resources, time devoted towards formal learning activities and the cultural viewpoints and perspectives among individuals and communities regarding the education of girls (White, Ruther, \& Kahn, 2016). Poverty is one of the major factors, which keep the girl child deprived from education as their parents consider them as burden of the family and give them in marriage early in life. About $85 \%$ of the people of the state are living in rural areas and majority of them are found to be living below poverty line. The customs, traditions and religious belief system in the society are also hampering the educational achievement of females in regional as well as in the national level.

\section{A. Statement of the Problem:}

The gender bias is one of the global issues that have been on the focus since ancient times. India is also facing the problem with regards to gender differences in the field of education, work participation, etc. The women are given less importance than the male in traditional Indian culture since the time immemorial. At present, the constitution of India is providing equal rights to woman to take part in any opportunities, be it education or work for all-round development in the country. Various educational programmes have also been launched by the government of India to provide equal opportunities to all. But still disparity between male and female are on the rise in terms of educational achievement in the society. There is less discrimination between male and female in the tribal societies in the north eastern India. But in case of Assam, there is preferential treatment of male and female. The district Dhubri is populated by various communities such as Muslims, Bengalis, Rabhas, Bodos, Garos, Asomiyas etc. and among these communities Muslims are in majority. If we have a look into the educational opportunities provided to various communities, it is observed that female Muslims are given less opportunities to attend schools among the communities. From that point of view, there is a wide gap between the educational achievement between male and female in Muslim society.

Published By:

Blue Eyes Intelligence Engineering \& Sciences Publication 
The female people are getting less opportunity to enjoy in various perspectives. And in terms of work participation, women are given the responsibility to look after the domestic affairs in the family as they are not allowed to do other activities especially in service sectors, which is also leading to gender bias in the society. Hence, the attitude towards the education and work participation of female in Muslim society should be changed and equal opportunities should be provided irrespective of gender. An emphasis on promoting a more diverse curriculum and increasing number of female teachers in the educational institutions is an attempt to reverse gender bias that girls experience in schools.

\section{B. Objectives: The following objectives are set forth for the study-}

The following objectives are set forth for the study.

1. To highlight the trend of growth of educational achievement of the male and female of Dhubri district.

2. To understand the educational gap between male and female of Dhubri district of Assam and

3. To identify the problems of female education and to put forward suggestions for removing the educational disparities between male and female in th district.

\section{The Study Area:}

The district Dhubri is situated extremely in the western part of Assam and lies between the latitude 26 degree 22 minute to 25 degree 28 minute north latitude and 89 degree 42 minute to 90 degree 12 minute east longitude and the average altitude of the district is $30 \mathrm{~m}$ from the mean sea level. Geologically, the district has young alluvial soil formation and rich in agricultural products because it is situated at the shore areas of Brahmaputra river.The district has the warm and temperate climate having the annual rainfall of 2,518 $\mathrm{mm}$ which can be considered as high rainfall zone. The district is falling under the Cwa category by Koppen's climatic classification with average annual temperature of 24.2 degree Celsius. The region is influenced by the south east monsoon. Dhubri is an administrative district in the state of Assam. The district headquarter is located at Dhubri town which is situated about $295 \mathrm{~km}$ away from Guwahati. The district is surrounded by Kokrajhar to the north, West Bengal in the west, Bangladesh and Meghalaya in the south and Goalpara and Bongaigaon district in the east.

Geographically, it occupies a total area of 2,838 square kilometers, covering $3.61 \%$ of the total landmass of the state. The total population of the district is 1,948,632 ranking second among the districts of Assam and the density of population is 896 persons per sq.km as per 2011 census. The sex ratio is 953 females per 1000 males. The district is populated by various communities such as Muslims, Rajbongshis, Bengalis, Rabhas, Bodos, Garos etc. The literacy rate of the district is 58.34 percent which is much lower than the state average i.e. 73.4 percent. The male and female literacy is 63.1 and 53.33 percent respectively.The district has three important sub-divisions - a) Dhubri (Sadar) (b) Bilasipara and (C) South Salmara-Hatsingimari, Mankachar.
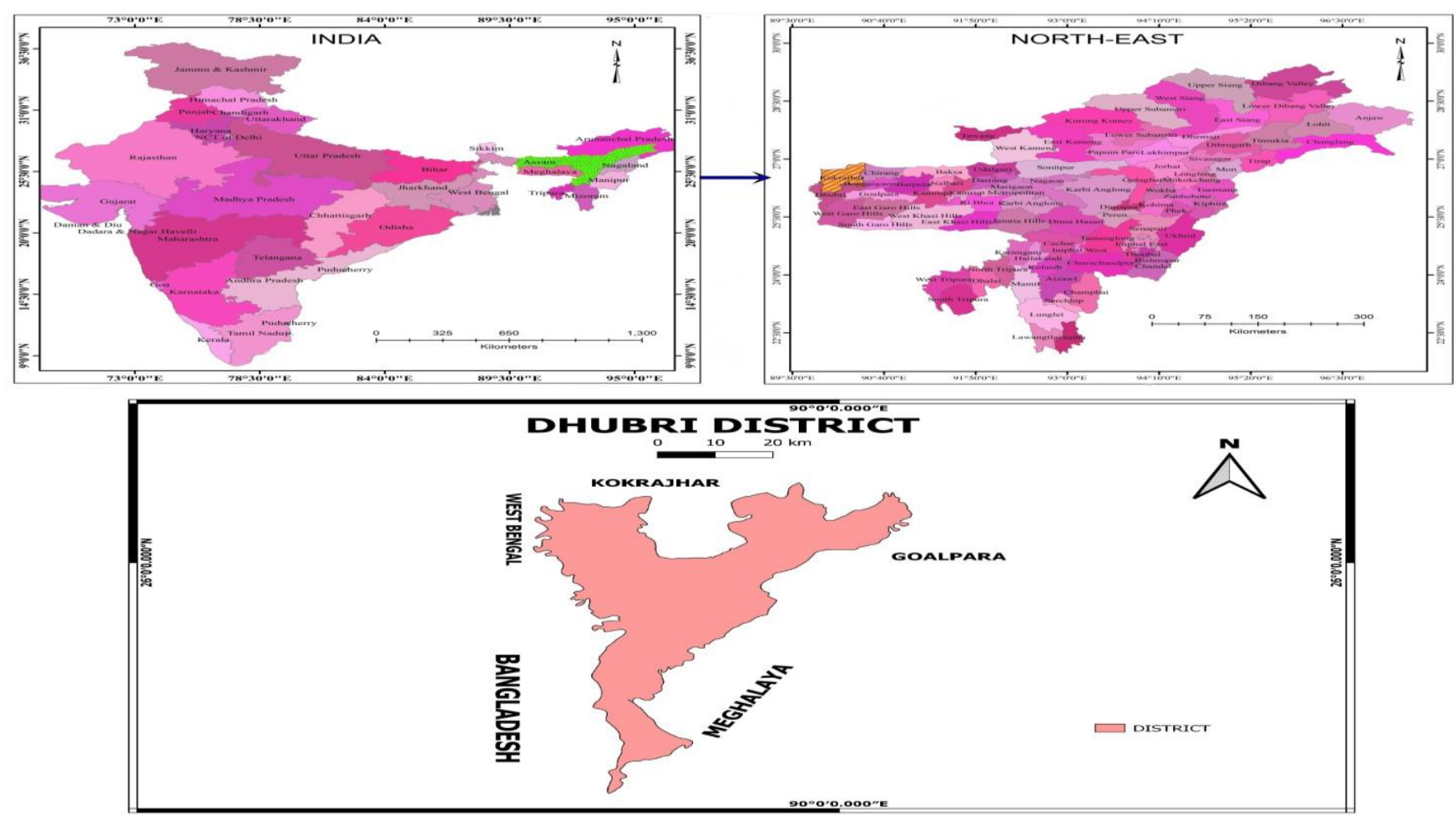

(Map of India, Assam, Dhubri district) 


\section{Methodology:}

The study is carried out randomly in three different villages namely Ghunimari, Bhakatpara and Gauripur of Dhubri district. The data is collected from both primary as well as the secondary sources. The questionnaire has been prepared as per the requirement of the study and about 126 samples have been selected on random basis from the villages of Puthimari, Paglahat, Ghospara, etc. The secondary data is mainly collected from books, articles, research papers and internet. Observational method is also applied. For better understanding of the problem, people from the three subdivisions of the district are interacted. The collected information is based on the gender differences of their educational achievement. The collected data has been formulated with the help of some statistical methods to show the differences. Data collected is put into the ms-excel to prepare necessary diagrams. The map of the study area has been prepared on QGIS by digitizing it on the Google Earth.

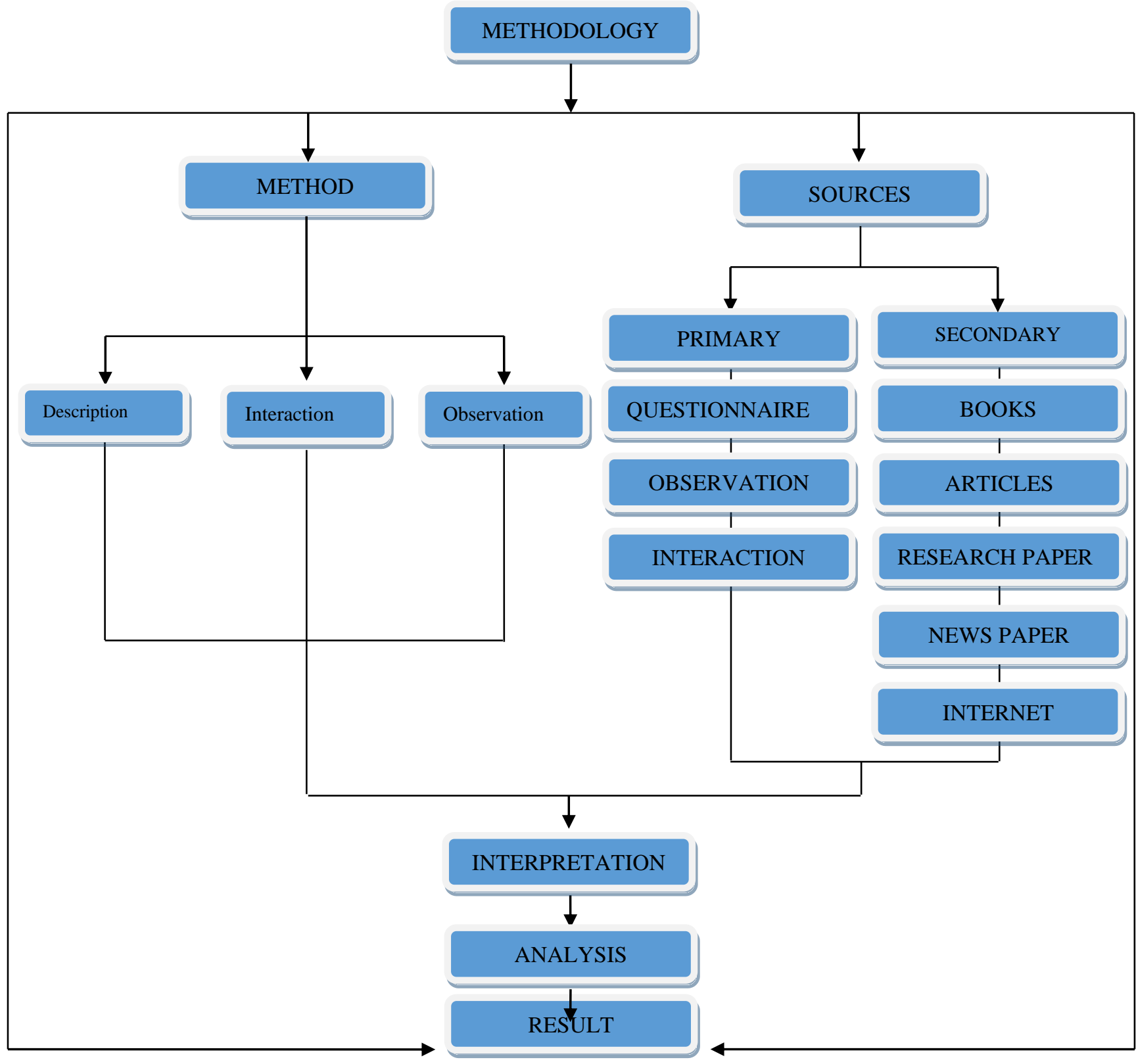

\section{LITERATURE REVIEW}

M. Niaz Asadullah and Gaston Yalonetzky (August 2010) are of the opinion that a society with unequal opportunities is said to be characterized by a low degree of social mobility, in that individuals' economic success/status is largely predictable in terms of family background such as caste and religion. Educational imbalances in India deserve particular attention because traditional social disparities based on notions of pollution and impurity that governed caste relations are rapidly being transformed into class inequalities through differential educational (Sonalde et.al. 2010). It is important to remedy educational inequalities since they can lead to inequality in economic and other adult domains (White et.al. 2016). More than half of the nation's schoolchildren are in racially concentrated district, where over 75 percent of student are either white or non-white the new (by Keith Meatto, York times, May 2, 2019).

Blue Eyes Intelligence Engineering \& Sciences Publication

and $\mathrm{Hu}$

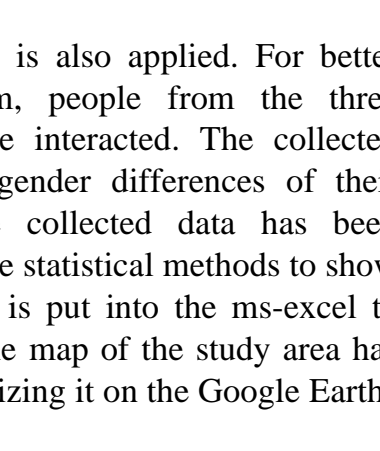

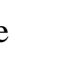

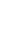

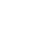

.

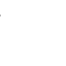


Several factors influence negative attitudes toward the education of girls. One concern relates to savings for dowry, which may limit the amount of funds that parents have to spend on daughters' education or create a fear that having educated daughters may result in having to pay higher marriage costs and dowry (White et.al. 2016).

\section{LITERACY RATE}

It is necessary for a person to be literate before he becomes educated. The Population Commission of UN has defined a person as literate who can read and write a simple message with understanding in any language can be considered as literate. The census of India says that a person aged seven and above, who can both read and write with understanding in any language is treated as literate. The district Dhubri is the second most populous district of Assam after Nagaon with 19,49,258 Person (2011) of which 9, 97,848 are male and 9, 51,410 are female. Though the district Dhubri has the second highest population in the state, it has the lowest literacy rate of $58.34 \%$ as per 2011 census with $63.10 \%$ male and $53.33 \%$ female. The population density is about 896 persons per sq. $\mathrm{km}$. which can be considered as very high population density region in the state of Assam as well as in the country. The district has about 9, 22,341 literate persons (2011) and out of this 5, 11,551 are male and 4, 10,790 are female. The number of illiterate people are also very high in the district as compared to the other districts of the state which is about $10,26,917$ persons and out of this 4,86,297 happens to be male and rest are females.

Literacy rate of Dhubri district, Assam and India, 2011.

\begin{tabular}{|l|l|l|l|}
\hline & Total (in\%) & Male & Female \\
\hline Dhubri & 58.34 & 63.1 & 53.33 \\
\hline Assam & 72.19 & 77.85 & 66.27 \\
\hline India & 74.04 & 82.14 & 65.46 \\
\hline
\end{tabular}

\section{Literacy rate of Dhubri district, Assam and India(2011)}

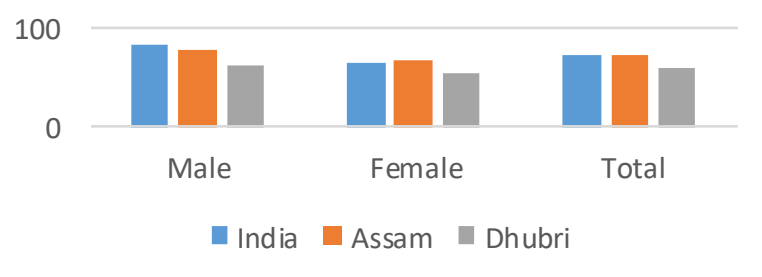

. The district has the average literacy rate of 58.34\% where the male literacy is $63.1 \%$ and female literacy is $55.33 \%$. The literacy rate of the district is very low as compared to the state average as well as national average. During the same year, the state average literacy rate is about 72.19 percent whereas it is much higher in the national level i.e 74.04 percent. The literacy rate gap between male and female is also very high in the district. The district has male literacy rate of 63.1 and the female literacy rate of 53.33 percent.

\section{A. Growth of literacy rate in the Dhubri District of Assam (1971-2011):}

Literacy growth is the changing of number of literate people between two different time periods. So, growth of literacy rate means increase or decrease in the number of people who are considered as literate between the two time periods. In 1971, the literacy rate of the undivided Goalpara district was very low i.e. $19.99 \%$ and the male and female literacy rate was $28.07 \%$ and $11.30 \%$ respectively (table 3.2 ). During the same period, the literacy rate gap between male and female was very high as compared to the state, which was 44.31 percent male and 23.52 Trend of growth of Literacy rate in Dhubri district.

\begin{tabular}{|c|c|c|c|c|c|c|}
\hline \multirow{3}{*}{ Dhubri } & \multicolumn{5}{|c|}{ Year (Literacy rate in percentage) } \\
\cline { 3 - 7 } & & 1971 & 1981 & 1991 & 2001 & 2011 \\
\cline { 2 - 6 } & Total & 19.99 & N.A. & 38.31 & 48.17 & 58.34 \\
\cline { 2 - 6 } & Male & 28.07 & N.A. & 47.32 & 55.84 & 63.10 \\
\cline { 2 - 6 } & Female & 11.30 & N.A. & 28.75 & 40.02 & 53.33 \\
\hline \multirow{4}{*}{ Assam } & Total & 34.60 & N.A. & 52.89 & 63.25 & 73.18 \\
\cline { 2 - 7 } & Male & 44.31 & N.A. & 61.87 & 71.28 & 78.81 \\
\cline { 2 - 6 } & Female & 23.52 & N.A. & 43.03 & 54.61 & 67.28 \\
\hline
\end{tabular}

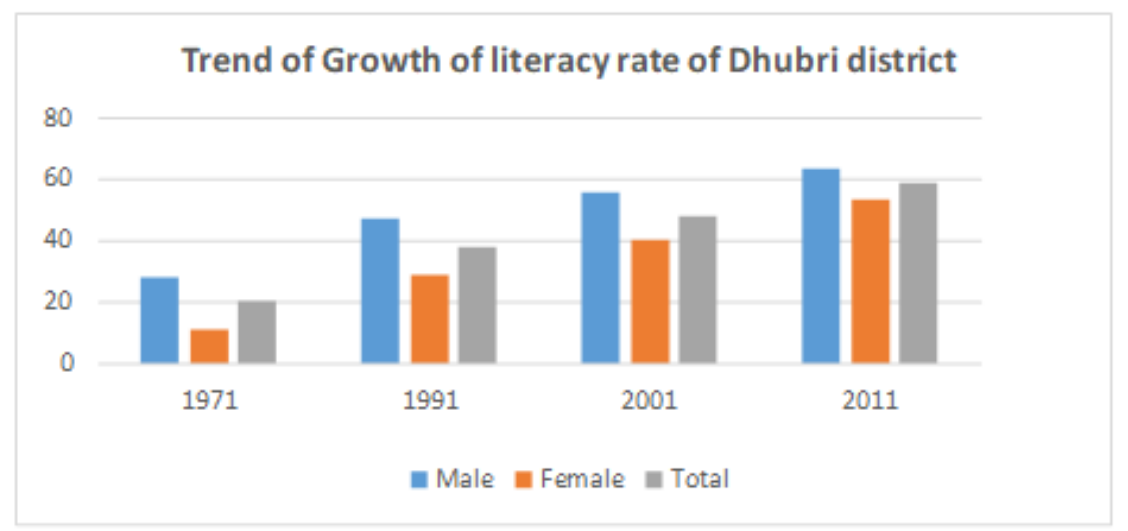


There is no data available for the year 1981 as the periodic census could not be conducted in the state due to the Assam movement which continued for six years commencing from 1979 to 1985 . From 1991, the literacy rate of the district was gradually increasing and it rose to $38.31 \%$ of which male and female literacy was $47.32 \%$ and $28.75 \%$ respectively. In 2001, the average literacy rate of the district increased to $48.17 \%$ with $55.84 \%$ male and $40.02 \%$ female. And in 2011, the literacy rate in the district jumped to $58.34 \%$ with 63.10 percent male and 53.33 percent female. This is due to the initiative taken by the state government to improve the quality of education in various levels. Still the literacy gap between male and female in the district is very high and even higher than the state where the state literacy rate is $73.18 \%$
(2011) with 78.81\% male and $67.28 \%$ female. The data reveals that the literacy rate of the district is improving over the decade and the gap between male and female literacy is reduced. The low literacy rate in the district has resulted into a number of negative consequences which are creating problem in the socio-economic development of the communities in the district.

\section{B. Educational Gap between male and female in Dhubri District of Assam:}

Educational gap between male and female in Ghunimari, Bhakatpara and Gauripur villages of Dhubri district.

\begin{tabular}{|c|c|c|c|c|c|c|}
\hline \multirow{2}{*}{$\begin{array}{c}\text { Class } \\
\text { (Number of Person) }\end{array}$} & \multicolumn{2}{|c|}{ 0-16 years } & \multicolumn{2}{|c|}{$17-35$} & \multicolumn{2}{|c|}{ 36-above } \\
\hline & $\mathbf{M}$ & $\mathbf{F}$ & $\mathbf{M}$ & $\mathbf{F}$ & $\mathbf{M}$ & $\mathbf{F}$ \\
\hline Below 10 & 39 & 23 & 10 & 15 & 37 & 23 \\
\hline H.S.L.C. & 25 & 22 & 27 & 17 & 20 & 16 \\
\hline H.S. & 00 & 00 & 36 & 30 & 26 & 14 \\
\hline BA and Above & 00 & 00 & 66 & 51 & 53 & 21 \\
\hline Illiterate & 08 & 11 & 12 & 09 & 15 & 33 \\
\hline
\end{tabular}

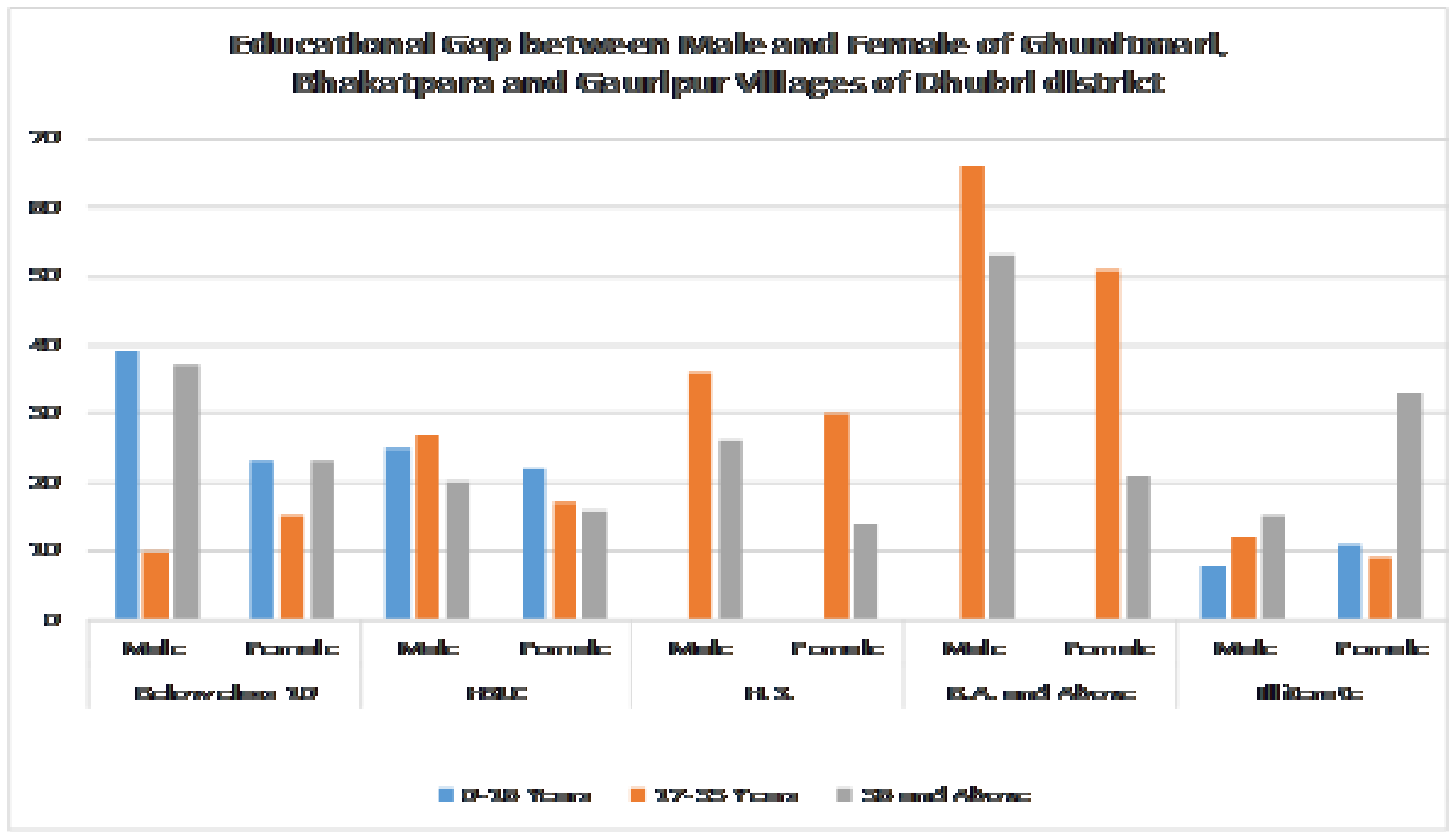


The total population of the surveyed villages is 569 persons. And out of this, the number of male and female literates is 339 and 232 respectively, which reflects that male literacy is quite high in the study area. The total number of illiterates is 88 persons of whom 35 are male and 53 are female. The number of class $\mathrm{X}$ passed male and female is 72 and 55 respectively. The number of female Higher Secondary passed is 44 and male is 62 , which is again less than the male. The number of male and female who passed their BA is 119 and 72 respectively. Here also male outnumbers the females. Hence, in all levels, the number of female educational achievement is lower than the male. From that point of view it is clear that the females are lagging far behind than males in the field of education

\section{FACTORS INFLUENCING GENDER DIFFERENCING ON EDUCATION IN DHUBRI DISTRICT:}

In India, despite improvements in educational access over the past several decades, social background is still found to be associated with learning outcomes (Gregory.et.al. 2016). Achievement gaps based on gender, region, and other social background factors often arise in primary school and many Indian children struggle against historical inequality based on gender and caste (Desai et al. 2010; Rao, Cheng, and Narain 2003; Probe Team 1999). In traditional view points most of the families of that region are busy in providing education to their boy children because women are always in passive role in their society and they are quite responsible for domestic activities only. Gender inequality may result from historical attitudes regarding the education of girls as well as certain parents choosing to prioritize sons' education over daughters' education (Gregory White.et.al). The educational investment on the children is also different to boys and girls. The parents are giving more opportunities to boy child than the girl child. Female Genital Mutilation (FGM) is identified as harmful to the well being of women and girls and contributed to low enrolment of girls in education (Linda 2014). The low participation of girls in education results from a combination of socio economic and cultural forces outside the school. Most of the girls are forced to marry during their student life which leads to the incompletion of the course. One concern relates to savings for dowry, which may limit the amount of funds that parents have to spend on daughters' education or create a fear that having educated daughters may result in having to pay higher marriage costs and dowry because giving education to the girl children is a kind of economic burden for them. But this is reverse to some of the tribal communities of the region. And it is also related to community and family attitudes regarding educational

\section{A. Socio-cultural attitude related to education of girls}

There are several factors associated with educational achievement of females in Dhubri district. The first and foremost factor is the social factor which is very much prevalent in the study area. As the area is dominated by the Muslim community, parents are not in favour of sending the girls to schools thinking that it will increase their burden on the education of other children. They also have the belief that attainment.

after having completed their education, they will be moving to grooms house. There is also tendency among the Muslim parents giving their daughters in marriage before they attain the age of 18 years which is not permitted legally. Majority of girls are getting married in early age among the Muslims as the law is not applicable to Muslim society. The child marriage system was prevalent even in ancient times and in India it is found to be prevalent from the time of Delhi Sultanate. During that time, parents forced their daughters to get married before they attain puberty to protect from foreign invaders. Hence, girls children were forced in marriage by their parents in early age. There was also thinking in the minds of parents and daughters that if the girls are not married in early age when opportunity comes, they might remain unmarried throughout. Though children were not interested to get married, parents used to compel their daughters in the past. Now the situation has changed and it is not the parents who force their daughters to marry early but the children themselves are creating the problem today and compelling the parents to agree to their marriage before time. This has been due to misuse of technology.

People in the study area are mainly engaged in primary activities such as agriculture, fishing, etc. So those children, who are from poor family, cannot have access to their education because their family cannot support them. Parents are mostly illiterate and they are not aware about education. However, instead of sending their girl children to the school, they prefer their daughters to be involved in the household activities to support the family.

As the study area is dominated by Muslim community, there is a tradition that females will have to be under Parda system (Cover their faces with cloth). Though this tradition is not that significant in the area still then it is also one of the reasons for keeping the girls away from schools.

\section{B. Access to high quality education}

The high quality education has also failed to reach the people in the rural areas of the district. Children are not encouraged today to go to schools by their parents in the villages as they have observed that the education system has failed to provide them with jobs after completing education. The poor parents have lost confidence on the education system after seeing that their children cannot do anything after attending schools for years. They prefer their children to be in the field rather than in schools as this will help them to earn more for the family.

\section{Lack of awareness}

Another factor which is responsible for low level of literacy among the girls in Dhubri district is the lack of awareness programmes on the significance of education in the district particularly in the rural areas.

Drop out from the school may be for numerous major and minor reasons such as economic conditions of family, school environment and other socio-cultural factors. Many children are withdrawn from the school before the completion of the course. 
Lower-income families may struggle to fund educational expenses and may have a higher demand for child labor (White et.al.). Many families are from low economic background and they hardly have any idea about the outcome of education.

\section{School Environment}

The school environment is also another important factor which influences the education of a particular region. Basically school environment mostly depend upon the society of a region. It has been argued that inadequate school facilities can also keep girls away, some school facilities can actually make it difficult for girls to go to school (Linda, 2014). Matured girls cannot carry out their studies comfortably due to inadequate infrastructural facilities like separate toilets, urinals etc. Inadequate supply of qualified teachers, lack of furniture, proper sanitary services, enough classrooms, special room for girls, teaching and learning materials etc also hinders girls education. Socially people of the district are not aware about education as compared to the other district of the state. Most of the people are from Muslim and Bengali society and they have transitional norm with west Bengal culture and their GDP is very low as most of them are daily wage earners. The geographical isolation is also a considerable factor for their unequal treatment of education because the district is located at the extremely western part of the state.

\section{SUGGESTIONS AND CONCLUSIONS}

\section{A. Figures and Tables}

a. Massive awareness programmes should be carried out in the entire district related to the importance of education.

b. Awareness on the negative impact of child marriage should be organised. Children should be asked to set their career goal in life, which will lengthen their educational years and keep them away from getting married early in life. Children should be reminded that there is age for everything such as age for marriage, age for voting right etc. If they are made aware about all this, there will be less problem related to child marriage in the society. The early marriage system and dowry system should be abolished from the society to uplift the status of women.

c. At the local as well as regional level, the government should take initiative to provide good educational facilities to promote the quality education especially for the girl child.

d. The reservation system for the weaker section of the society as well as for the girl child should be implemented.

e. Government should establish girls schools and colleges to minimize the educational gap between male and female in the district.

f. Providing scholarships and other incentives to reduce the financial stress on the family will help in reducing the educational gap between male and female and also will motivate the children to continue their education.

In conclusion it may be said that the district Dhubri has miserably failed to bring awareness to the people in the district pertaining to the significance of education, negative impact of existing mindset of the people on education and social taboos, which resulted into the disparities in the educational attainment between male and female in the district. As the district is experiencing inequalities in educational achievements between male and female, the suggestions put forward will be able to bridge the gap between the two. If implemented, many problems faced by the society currently in the district such as poverty, child marriage, low standard of living, less preference to girls education etc. will get resolved and there will be equal opportunity for all in every aspect.

\section{REFERENCES}

1. https://www.researchgate.net/publication/334162862_Gender_Inequalit $\mathrm{y}$ in Education

2. https://women-s.net/gender-equality-in-education/

3. https://www.censusindia.co.in/district/dhubri-district-assam-301

4. India Human Development Survey fieldwork, data

5. Census 2011 Data - censusindia.gov.in

6. Dhubri, Assam-Wikipedia

7. https://www.census2011.co.in/census/district/148-dhubri.html

8. shodhganga.inflibnet.ac.in/bitstream/10603/8998/19/19_appendix.pdf

9. www.census2011.co.in/census/state/districtlist/assam.html

10. District report, Dhubri, ministry of minority affairs, government of India.

11. District census handbook Dhubri, Census of India (2011), Directorate of census operations, Assam 2011.

12. Brief Industrial Profile of Dhubri District, MSME-Development Institute, Bamunimaidam, Guwahati, Assam.

13. Govt. of Assam, Directorate of economics and Statistics- Statistical Handbook of Assam, 1974.

14. Probe Team. 1999. Public report on basic education in India. New Delhi: Oxford University Press.

15. Asadullah M. Niaz et.al. "Inequality of Educational Opportunity in India: Changes over Time and across States". ForschungsinstitutzurZukunft der Arbeit Institute for the Study of Labor Discussion IZA DP No. 5146, August 2010.

16. Bhagat, C. What Young India Wants, Selected Essays and Columns, Rupa Publications India Pvt. Ltd. New Delhi, 2012,p.111

17. Desai. S. Social Inequalities in Education. 2010

18. Desai, Sonalde, Amaresh Dubey, Brijlal Joshi, Mitali Sen, Abusaleh Shariff, and Reeve D. Vanneman. Human Development in India: Challenges for a Society in Transition. New York: Oxford University Press ,2010

19. Kapur, R. Gender Inequality in Education, 2019

20. Khullar, D.R, INDIA- A Comprehensive Geography, Kalyani Publishers, New Delhi, 2016, p.403

21. Linda $Z$ "FACTORS CAUSING GENDER INEQUALITY IN EDUCATION IN TANZANIA: A CASE OF KOROGWE DISTRICT SECONDARY SCHOOLS" UNIVERSITY OF TANZANIA, 2014

22. Meatto. K. "Still Separate, Still Unequal: Teaching about School Segregation and Educational Inequality". The New York Times, May 2 2019.

23. Nayar, U. "Education of girls in India: An assessment." Pp. 35-46 in India Education Report, edited by R. Govinda. New Delhi: National Institute ofEducational Planning and Administration and Oxford University Press, 2002

24. Sundaram, Aparna and Reeve Vanneman "Gender differentials in literacy in India: The intriguing relationship with women's labor force participation." World Development 36:128-143, 2008

25. White, Gregory.et.al. Educational Inequality in India: An Analysis of Gender Differences in Reading and Mathematics, India Human Development Survey, Working Paper No. 2016-2 


\title{
AUTHORS PROFILE
}

Gwmsath Mushahary has completed his graduation with honours in Geography from Gossaigaon College, Gossaigaon and masters degree from Department of Geography, Bodoland Universit with specialization in Geomorphology in .He was born in February, 04, 1994 in a remote village of Mojatigaon, Kokrajhar, Assam. Mr. Mushahary is currently teaching Geograpahy at Gossaigaon College as Guest lecturer.

\begin{abstract}
Dr. Manjil Basumatary has completed his masters degree in Geography from Nort Eastren Hill University (NEHU), Shillong in the year 1995 and Ph. D. from Gauhati University in 2010. Dr. Basumatary is currently teaching Geography in Under graduate (UG) and Post Graduate(PG) level at Gossaigaon College, Gossaigaon, Kokrajahr, Assam. He is a seasoned writer and publishes articles pertaining to the issues related to the western part of Assam. His area of interest is Peace and Conflict studies and has published papers related to conflict in the region in various journals and magazines. Dr. Basumatary has also presented number of papers at the national and international conferences held in the country and abroad related to conflict and other issues of the region. Besides teaching, Dr. Basumatary has also undergone National Cadet Corps (NCC) training for a eriod of three months at the Officers Training Academy (OTA), Kamptee, Nagpur in 2008 and commissioned as Lieuftenant and thereafter promoted to the rank of Captain in the NCC in 2014.
\end{abstract}

